OSMANLI İMPARATORLUĞU’NDA BÜTÇE DENGESİNIN GELIŞİMİ: 1643-1918

DOI NO 10.5578/jeas.10886

Şahin Yeşilyurt ${ }^{*}$ Mehmet Cural $^{* *}$

Öz

Bütçeler, devletlerin sahip oldukları fonksiyonları yerine getirmede tarihsel süreç içerisinde önemli görevler üstlenmişlerdir. Osmanlı İmparatorluğunda bütçeler, maliye politikası aracı olmaktan ziyade hükümdar nezdinde hesaplara kesinlik kazandırmak amacı taşımış ve bütçe kayıtlarının tutulmasına önemle uyulmuştur. Bu kapsamda çalışmada Osmanlı İmparatorluğunun 1643-1918 yılları arasındaki bütçe gelir-gider miktarları ve bütçe dengesi incelenmektedir. Çalışma sonuçlarına göre İmparatorluğunun askeri ve siyasi anlamda güçlü olduğu dönemlerde bütçe fazlasının oluştuğu; askeri ve siyasi anlamda zayıf olduğu dönemlerde ise bütçe açığının oluştuğu ortaya çıkmıştır. Bütçe açıklarının, özellikle 18. yüzyıldan sonra arttı̆̆ı ve 19. yüzyılda kronik bir hale dönüştüğü görülmüştür.

Anahtar Kelimeler: Maliye Tarihi, Osmanlı Maliyesi, Osmanlı Bütçe Dengesi

JEL Kodlar1: B10, B12, Z12, H62

\title{
THE EVOLUTION OF BUDGET BALANCE IN THE OTTOMAN EMPIRE:
}

\section{3-1918}

\section{Abstract}

Budgets play an important role in the historical process in order to fulfill the functions that states have. In the Ottoman Empire, budgets were not regarded as a monetary policy tool but had aim in making accounts certain, and a record of budgets was carefully kept. In this paper, the Ottoman Empire's Budgets revenues and expenses and budget balance between 1643 and 1918 are investigated. According to the findings of this paper, when the Ottoman Empire had strong military and political powers, budget deficit occured; however, when the Ottoman Empire had weak military and political powers, budget deficit took place. The budget deficit in particular after the 18th century increased and in the 19th century it turned out to be cronic.

Keywords: Public Finance History, Ottoman Public Finance, Ottoman Budget Balance

${ }^{*}$ Yıldırım Beyazıt Üniversitesi, S.B.F.

${ }^{*}$ Yrd. Doç. Dr., Bülent Ecevit Üniversitesi, İ.I.B.F. 


\section{GİRIŞ}

Devlet bütçeleri ekonominin genel performansındaki gelişme ve değişmelerin izlenmesine imkân verecek önemli bir göstergedir. Batı toplumlarında bütçe hakkı, modern ulus devletlerin ortaya çıkışıyla paralellik göstermiş, sosyal, iktisadi ve mali gelişmeler bütçe hakkı kavramının önemini artırmış, milli kaynakların kullanılması sorununun aşılmasında kullanılan temel araç olmuştur. Osmanlı İmparatorluğu maliyesinde bir bütçe geleneğinin olduğu, ancak bu bütçelerin gerek batılı ülkelerde gerekse de günümüz modern parlamenter sistemlerde kullanılan bütçelerle bir takım farklılıkların olduğu yadsınamaz bir gerçekliktir. Bununla birlikte Osmanlı maliyesinin en köklü geleneklerinden biri olan bütçe kayıtları, merkezi hazinenin gelir ve giderlerini en küçük ayrıntılarına kadar takip etmemize olanak tanımaktadir.

$\mathrm{Bu}$ bağlamda çalışmada, Osmanlı İmparatorluğu'nda 17'inci yüzyıl ile 20'nci yüzyılın ilk yılları arasında bütçe gelir ve giderleri ile bütçe dengesinin durumu analiz edilmektedir.

Çalışmada Osmanlı maliyesinde yaklaşık 300 yıllık bir süreçte 138 yılın bütçesi analiz edilebilmiştir. Ele alınan dönem, Osmanlı İmparatorluğu'nun duraklama ve çözülüş döneminin tarihidir. Çalışmanın amacı, mevcut veriler ışı̆̆ında, Osmanlı kamu finans tarihine 1şık tutmaktır. Çalışma esas olarak iki bölümden oluşmaktadır. İlk bölümde bütçe kavramı ve bütçenin tarihsel gelişimi açıklanmaktadır. İkinci bölümde ise alt başlıklar altında Osmanlı İmparatorluğu'nda 17'inci yüzyılın ortasından başlayarak, 18'inci, 19'uncu ve 20'inci yüzyıllarda bütçe dengesinin seyri ve bütçe gelir ve giderlerine oranı analiz edilmektedir.

\section{BÜTÇE KAVRAMI VE BÜTÇENIN TARIHSEL GELIŞSIMI}

Devletin gelir ve gider kalemleri arasındaki ilişkiyi gösteren bütçeler, tarihsel süreç içerisinde devletin iktisadi, mali, hukuki, siyasi ve sosyal alanlarda faaliyet göstermesinde önemli bir rol üstlenmiştir. Bütçeler, üstlenmiş oldukları bu rolü günümüzde genişleterek sürdürmektedir. Modern parlamenter sistemlerde bütçeler, yürütme organının yasama organından aldığı yetki neticesinde kamu harcamalarının yapilmasinda ve bu harcamalarin karşılanmasında kullanılan kamu gelirlerinin toplanmasında önemli bir yer almıştır.

Bütçe, Latince kökenli bulga kelimesinden türemiş olup, zamanla Fransizcaya bouge, bougett olarak geçmiş ve 17. yüzyılda budget kelimesiyle İngilizceye geçmiştir. Bu süreçten dolayı bütçenin kavram olarak batı ülkelerinde ortaya çıktığı ve oradan geliştiği iddia edilmektedir (Tüğen, 2014:1). Bu çerçevede bütçe alanındaki ilk gelişmenin yönetimin (kralların ya da padişahların) vergi toplama yetkisinin sınırlandırılmasıyla ortaya çıktığı (Magna Carta1215) kabul edilmektedir. İlerleyen süreçte kamu harcamalarının belirlenmesinde kisitlamalar getirilmiş (Haklar Dilekçesi-1627 ve Haklar Yasas1-1689) ve bütçe gelir ve giderlerinin her yıl mecliste görüşülmesiyle bütçe hakkının ortaya çıktığı belirtilmektedir. $\mathrm{Bu}$ gelişmelerin neticesinde vergi toplama ve gider yapma yetkisi olan bütçe hakkının kurumsallaşmasında 1783 Amerikan Bağımsızlık savaşı ve 1789 Fransız İhtilali sonucunda yapilan anayasal düzenlemelerin önemli etkileri olmuştur.

Batı toplumlarında bütçe hakkı, modern ulus devletlerin ortaya çıkışıyla paralellik göstermiş ve mutlak monarşiden temsile dayalı ulus devlete geçişte hem işlevsel bir rol üstlenmiş hem de bu değişimin en temel belirleyicisi olmuştur (Bağlı, 2012:39-41). Bütçe hakk1 ile ulus devlet kavramlarının birbirinin nedeni ve sonucu olduğu; bir milletin (ulus devletinin) kendi kendini yönetmesinin en temel koşulunun bütçe hakkı olduğu belirtilmiştir (Feyzioğlu, 1983:3). Ulus devlet kavramılla birlikte gelişen bütçe hakkı, aynı zamanda, egemenlik kavramı çerçevesinde ele alınmış ve mali egemenlik kavramıla birlikte ayrılmaz bir bütün olarak kabul edilmiştir. Milli egemenlik alanında yaşanan gelişmelerin yanı sıra sosyal, iktisadi ve mali gelişmeler bütçe hakkı kavramının önemini artırmış, toplumların yönetim erkiyle doğrudan ilişki kurmalarının yolları açılmış ve toplumsal yapının şekillenmesinde önemli bir eşik atlanılmıştır

Batı ülkelerinde yaşanan bu süreç hiç kuşkusuz tüm dünya devletlerini etkilemiş ve ulus-devlet ilişkisiyle devletlerin siyasi anlamda dönüşmesinde etkin roller üstlenmiştir. Dünya 
çapında yaşanan bu değişmeden önemli ölçüde etkilenen devletlerin başında gerek çok uluslu olması gerekse de yaşanan kapitalist devrimden derinden etkilenmesinden dolayı Osmanlı İmparatorluğu gelmektedir.

\section{OSMANLI IMPARATORLUĞU'NDA BÜTÇENIN GELIŞIMIMI}

Osmanlı İmparatorluğu'nda devlet hazinesinin yıllık gelir ve gider rakamlarını içeren cetveller kuruluşundan itibaren kullanılmıştır. Sahillioğlu (1967:79-80) bu cetvellerin, Tanzimat dönemine kadar hazinenin gelir ve giderlerini gösteren tablolar olduğunu ve modern anlamda bir bütçe olmadıkların belirtmektedir. Ayrıca bu cetvellerin, envanter yahut kesin hesap mahiyetinde olduğunu, çoğunlukla yılsonunda tutulan hesap özetleri niteliğinde olmalarından dolayı günümüz anlamında bir bütçe kavramını karşılamada yetersiz olduklarını ileri sürmektedir. Ancak Tabakoğlu (2005:183), bu cetvellerin bütçe olarak tanımlanmasında bir yanlışlığın ve eksikliğin olmadığını ifade etmektedir.

Osmanlı İmparatorluğu maliyesinde bir bütçe

geleneğinin olduğu, ancak bu bütçeler ile günümüz modern parlamenter sistemlerde kullanılan bütçeler arasında bir takım farklılıkların olduğu yadsınamaz bir gerçekliktir. Nitekim Osmanlı bütçelerinin gelecek yıllara ilişkin tahminlerden ziyade geçmiş yıla ilişkin kesin gelir ve gider rakamlarından oluştuğu, hükümdar nezdinde hesaplara kesinlik kazandırmak gibi bir amaç güdüldüğü, birbirini izleyen mali yıllarda sürekli düzenlenmiş belgelerden ziyade tesadüfen korunabilmiş bir takım kısmi göstergelerden oluştuğu, gelir ve gider kalemleri arasında tekdüzeliğin olmadığı, merkezi devlet dışı özerk bütçeleri içermediği, bir takım muhasebeleştirilmemiş gelirler olduğu söylenebilir (Gürsakal, 2010:118: Eser, 1982:171).

Günümüz parlamenter sistemlerinde bütçeler, tek bir çatı altında toplanmakta ve kavramsal olarak birlik ve genellik ilkesi çerçevesinde uygulanmaktadır. Bu ilkeler gereğince bütçeler, bir bütün olarak kabul edilmekte ve bu bütçelerden belli harcama alanlarına gelir tahsis

\footnotetext{
1 Tımar sistemi, geçimlerini veya hizmetlerine ait masrafları karşılamak üzere bir kısım asker veya memurlara belirli bölgelerin kendi ad ve hesaplarına
}

edilmemekte ve gelirler gayrisafi usul çerçevesinde, gelir ve giderler mahsup işlemi yapılmadan, kaydedilmektedir. Ancak Osmanlı İmparatorluğunda bütçeler, birlik ve genellik ilkesinden uzak bir çerçevede ele alınmış ve bütçelerde tahsis ilkesi ve gayrisafilik ilkesi göz ard 1 edilmiştir.

Osmanlı'da bütçe gelirleri başlıca zekât, öşür, haraç ve cizyeye dayanmaktaydı. Osmanlı merkezi bütçesi, merkez bürokrasisi olan Divan-1 Hümayun ve buna bağlı kalemler, şeyhülislam ve ilmiye teşkilatı, askeri teşkilat, defterdarlık ve maliye teşkilatlarının giderlerinden ibaretti. Merkezi bütçeye ilave olarak eyalet ve vakıflar bütçeleri bulunmakta ve merkez bütçeleri bunlardan aktarılan gelirlerle birlikte hesaplanmaktaydı. Eyalet ve vakıflar kendi gelirleri ile giderlerini karşılamakta ve gelir fazlalarını merkeze göndermekteydiler. Dolayısıyla Osmanlı merkez bütçeleri, birçok kamu hizmetinin yerelde ve yerinden, vakıflar aracılığıyla, gerçekleştirilmesi sonucu miktar olarak küçük kalmıştır (Parlak ve Parlak, 2012:22).

Başka bir ifadeyle toplanan gelirlerin tamamı bütçeye dâhil edilmemiş;; çeşitli bölgelerden toplanan vergi gelirleri, has, zeamet ve tımar şeklinde veya çeşitli imtiyaz ve vergi muafiyetleri durumunda askeri ve idari hizmetlerin karşılığı olarak bırakılmış, bazı vergiler ise dini, kültürel veya toplumsal açıdan karşılanması gereken bazı ihtiyaçların giderilmesi adına kurulmuş olan vakıflara tahsis edilmiştir (Barkan, 1955:194-195). Bu bağlamda merkezi bürokrasi, yarg1 örgütü ve taşra yönetiminde çalışan kadrolara yapılan maaş ödemelerini karşılayan tımar sisteminin ${ }^{1}$ ve bu kadrolara tahsis edilen harç, avaid ve caiz gibi birtakım gelirler bütçelerde yer almamıştır (Genç ve Özvar, 2006:8-10).

Osmanlıda bütçe hakkı, padişah tarafından kullanılmıştır. Padişahın bütçeye ilişkin yetkileri ilk defa 1876 Tanzimat Fermanı (Kanun-ı Esasi) ile kısıtlanmaya başlanılmıştır. Bütçe hakkıyla ilgili gelişmeler batıda halk hareketleri sonucu meydana gelen temsili demokrasiyle parlamentoların tek yetkili olmasiyla neticelenmiş iken Osmanlıda merkezi yöneticiler tarafından devletin kurtarılması

tahsis edilmiş, yılık geliri 20.000 akçeye kadar olan askeri dirlikler şeklinde tanımlanmaktadır. 
amacıyla getirilen düzenlemeler şeklinde olmuştur (Yilmaz ve Biçer, 2010: 203-204). Tanzimat Fermanı'nda kanuni dayanağı olmaksızın kimseden vergi ve resim adı altında para tahsil edilemeyeceği, devlet gelir ve giderlerinin her yıl Muvâzen-i Umumiye Kanunu'yla tasdik edildikten sonra uygulanacağı ve vergilerin tahsiline bütçe kanunuyla her yıl yeniden izin verilmesi gerektiği belirtilmiştir. Ancak bu esaslar, $1908^{\prime}$ de II. Meşrutiyet'in ilanına kadar fiilen uygulanamamış, vergilerin padişahların iradeleriyle toplanmasına ve padişahın uygun gördügü yerlere harcanmasına devam edilmiştir (Şahin, 2013:862).

Osmanlı maliyesinde bütçeyle öngörülen gelirlerin toplanmasina ve belirlenen harcamaların yapılmasına önceden tasdik yoluyla izin veren bir doküman anlamında ilk modern bütçe Güran (2003)'a göre 1846/47 mali yılında, T.C. Maliye Bakanlığg' ${ }^{2}$ na göre ise 1863 yılında hazırlanmıştır. Bununla birlikte Osmanlı İmparatorluğu bütçe geleneğine hemen hemen her koşulda ve zamanda riayet etmiş, ekonomik buhran ya da olağanüstü dönemlerde hazırlanan bütçelerin çoğu zaman açık vermesi durumunda bile aynı yıl içerisinde birden fazla bütçe hazırlanmıştır (Genç ve Özvar, 2006:1214).

Bu bağlamda çalışmada Osmanlı maliyesinde 17. yüzyıl ile 20. yüzyılın ilk yılları arasında bütçe dengesi analiz edilmektedir. Ancak yaklaşık 300 yıllık bir sürecin ele alınması birtakım kısıtların meydana gelmesine neden olmuştur. Bu kısıtların en başında birçok yılın bütçe rakamlarının olmaması gelmektedir. Bununla birlikte hemen hemen her yüzyıldan olmak üzere (17'inci yüzyllda 28 yll, 18'inci yüzyılda 44 yıl, 19'uncu yüzyılda 49 yıl, 20'inci yüzyılda 17 yıl) toplam 138 yılın bütçe rakamları tespit edilebilmiştir. Çalışmada bir diğer kısıt olarak, uzun zaman diliminde fiyat artışlarının gerçekleşmesi nedeniyle paranın değerinde meydana gelen değişimlerin dikkate alınması

\footnotetext{
2 http://www.maliye.gov.tr/Tarihce/Bakanl\%C4\% B1k\%20Tarihcesi\%20.pdf

${ }^{3}$ Pamuk (2000:3-18), bu endeksin oluşturulmasında üç ayrı kaynaktan yararlanmıştır. Bu kaynaklar ise ilk olarak İstanbul'daki büyüklü küçüklü vakıfların ve bunlara ait imarethanelerin hesap defterinden, ikincisi Topkapı Sarayı tarafından alınan gıda mallarının fiyatlarından ve üçüncü ise
}

gerekmiştir. Zira bütçe gelir ve gider kalemlerinde meydana gelen değişimlerin cari fiyatlarla değerlendirmeye tabi tutulması yetersiz ve/veya yanlış sonuçların ortaya çıkmasına yol açacaktır. Bu nedenle söz konusu yıllara ilişkin cari rakamlar Şevket Pamuk tarafından oluşturulan İstanbul Tüketici Fiyatları Endeksi (1469-1918)3 kullanılarak reel hale dönüştürülmüştür.

\subsection{Yüzyıl'da Osmanlı İmparatorluğu'nda Bütçe Gelişmeleri}

Osmanlı İmparatorluğu'nda 16. yüzyıl bütçeleri merkez ve taşra eyaletleri gelir-gider rakamlarından oluşan derleme bir yapıda iken 17. yüzyıl bütçelerinde merkeziyetçi yapıya gidiş sonucu taşra eyaletlerinin gelir ve gider hesapları merkez maliye teşkilatının kalemlerine dağıtılmış bulunuyordu (Tabakoğlu, 1985:393). Bu dönemde bütçe gelirleri, özellikle, cizye, avarız ve mukataa kaynaklarından oluşmuştur. Devlet gelirlerinin bir süreliğine mültezimlere kiralandığ $\breve{g}_{1}$ ukataa sistemi, özellikle peşin ödemeyle yapılması ve artan oranlılığ sayesinde bu dönemde artmaya başlayan bütçe açıklarının kapatılmasında önemli rol oynamıştır (Genç ve Özvar, 2006:16).

Bütçe gelirlerinden Avarız vergileri, özellikle savaş ve buhran gibi olağanüstü dönemlerde alınan ek bir vergidir. Avarız vergileri, miktarının belirlenmesinde devlete esneklik sunduğundan önemli bir gelir kaynağ olmuştur. Avarız vergilerinin bu esnekliğine rağmen optimal vergi sınırını aşmadığı ve tam anlamıyla kullanılmadığı belirtilmektedir. Bu düşünceyi destekleyen en temel argüman ise devletin bütçe açılarının varlığına rağmen bu gelir kaynağına fazla başvurmaması ve bunun yerine ya devlet adamlarından, zengin tüccarlardan ya da iç hazineden kısa vadeli borçlanması gösterilmektedir. Ayrıca bütçe açıklarının kapatılmasında gelirleri artırmak yerine giderleri kısmak veya maaş ve ulufelerin geciktirilmesi yoluyla devletten alacağı olanlara gelecek yıllarda ödenmek üzere hazine tezkireleri

İstanbul kent yönetiminin loncalara danışarak her mal için ayrı ayrı belirlediği narh fiyatlarından meydana gelmektedir. Ayrıca fiyat endeksinin oluşturulmasında sadece İstanbul'un esas olarak belirlenmesinin en önemli nedeni ise Osmanlı İmparatorluğu en ayrıntılı fiyat verilerin burada olmuş olması ve İmparatorluk içerisinde sahip olduğu nüfus yoğunluğudur. 
verilmesi bu düşünceyi destekler niteliktedir (Genç ve Özvar, 2006:16-17). Ancak halka yüklenecek yeni vergilerin ödenmesinde güçlüklerin ortaya çıkabileceğinden ötürü devletin bu gelir kaynağına başvurmadığı ileri sürülebilir.

17.yüzyılın sonlarında kazanılan savaşlar ve fethedilen yerler ile iktisadi alanda yaşanan gelişmeler bütçe gelirlerinin artmasını sağlarken öte yandan savaş harcamaların artması, fethedilen yerlerde teşkilat yapısının oluşturulması ve idari alanda geliştirilmesi ve korunması bütçe giderlerini artırmıştır (Barkan, 1955:195-196). Bütçe giderlerini etkileyen bir diğer faktör ayan ve erkânın yaşamış olduğu lüks hayat tutkusudur. Ayan ve erkânın lüks yaşam tutkusu orta gelirli insanların bu kesimlere özenmesine yol açmış (Tabakoğlu, 2005:402), bu durum ise devletten daha fazla hizmet talep edilmesine ve dolayısıyla kamu harcamalarının artmasına neden olmuştur.

$\mathrm{Bu}$ yüzyılda vergi gelirlerinin toplanmasında Ayanlar önemli görevler almışlardır. Öyleki toplam vergi gelirlerinin yaklaşık üçte ikisi taşrada bulunan ayanlar ile merkezdeki bürokratlar ve vergi toplama sürecinde finansör görevi gören sarraflarda kalmıştır. Bu ilişki neticesinde ayanların savaş dönemlerinde orduya asker göndererek hazineye yansımayan bir katkı sunduğu belirtilebilir. Bu destekleme durumu ise devletin mali durumunu güçlendirmiştir (Karaman ve Pamuk, 2009:2830). Ancak ayanlar ile merkezi hükümet arasında genel olarak vergi toplama ve orduya asker sağlanması, her iki kesim tarafından temkinli yaklaşılması neticesinde, siyasi anlaşmaya dönüşememiştir.

17. yüzyılda olumsuz ekonomik ve mali koşullar Osmanlı İmparatorluğu'nu askeri, idari ve mali alanlarda birtakım merkeziyetçi reformlara zorlamıştır. Reformlar, merkezi yönetimin kaynak ihtiyacını artırmış, kaynak ihtiyacının karşılanmasında; tağşiş, iç borçlanma ve merkezi yönetim vergi gelirlerinin toplanmasında aracıların gücünü azaltma gibi yöntemler kullanılmıştır (Karaman ve Pamuk, 2009:30-31). Tağşişe, mali, askeri ve yönetim alanında güçlü olunan II. Mehmet (1441-1481) döneminde başvurulduğu gibi bu yüzyılda mali, askeri ve yönetim alanındaki zayıflıktan dolayı giderek kötüleşen bütçe dengesinin sağlanması, olağanüstü mali koşulların düzeltilmesi ve içinde bulunulan günlük hayatın kurtarılması amaçlarıyla başvurulmuştur (Pamuk, 2012:55-56).

$\mathrm{Bu}$ yüzyılda diğer bir finansman kaynağı padişahın sorumluluğu altında bulunan İç Hazine (Hazine-i Enderun, Hazine-i Hassa)'den alınan iç borçlanmalardır. Osmanlı İmparatorluğu'nda genel olarak İç Hazine ve Dış Hazine (sadrazamın ve defterdarın yönetiminde olan) olmak üzere iki hazine bulunmaktaydı. İç hazineden dış hazineye özellikle ödeme sıkıntılarının yaşandığı olağanüstü dönemlerde kaynak aktarımı yapılmış ve mali sıkıntılar bertaraf edilmeye çalışılmıştır. Ancak 17.yüzyılın sonlarında sosyal, siyasi ve ekonomik sıkıntılar neticesinde iç hazineden alınan borçların miktarı artmış ve artık devlet düzeyinde olağan bir gelir haline gelmiştir (Tabakoğlu, 2006:51-52).

Öte yandan devlet, sarraflardan iç borç almaya başlamış, bu ilişki sonraki yüzyıllarda artarak devam etmiş ve 19. yüzyılda doruk noktasına ulaşmıştır. Bu süreçte borç verme işlerinde uzmanlaşan sarraflar, oluşturdukları Lonca vasıtasıyla 19. yüzyılın birinci yarısından itibaren Galata Bankerleri olarak adlandırılan büyük sermaye grubuna dönüşmüşlerdir (Pamuk, 2006:33-34). Dolayisıyla Galata Bankerlerinde meydana gelen yükselmenin temellerini Osmanlı İmparatorluğu bütçe dengesinde oluşan açılarda bulmak mümkün görülmektedir.

17. yüzyılda yaşanan mali bunalımı Şekil 1'de izlemek mümkündür. Şekildeki veriler çoğunlukla bu yüzyılın ikinci yarısına aittir. Bu yüzyılda ele alınan bütçeler artan harcamaların finans güçlükleri nedeniyle açıkla kapanmaktadır. Bütçe gelir ve giderleri, genel eğilim olarak yüzyılın başından 1686/87 yılına kadar yarıdan fazla azalmış, bu yıldan sonra tekrar artarak yüzyılın başındaki değerlere ancak ulaşmıştır. Bütçe gelirleri ortalama 91 milyon kuruş (en düşük 66 milyon, en yüksek 141 milyon kuruş); bütçe giderleri ise ortalama 100 milyon kuruş (en düşük 36 milyon, en yüksek 159 milyon kuruş) gerçekleşmiştir. 17. yüzyıl ile 16. yüzyılda bütçe gelir ve gider miktarları birbirine oldukça yakındır. 
Şekil 1: 17. Yüzyılda Osmanlı İmparatorluğu Bütçesi, Milyon Kuruş

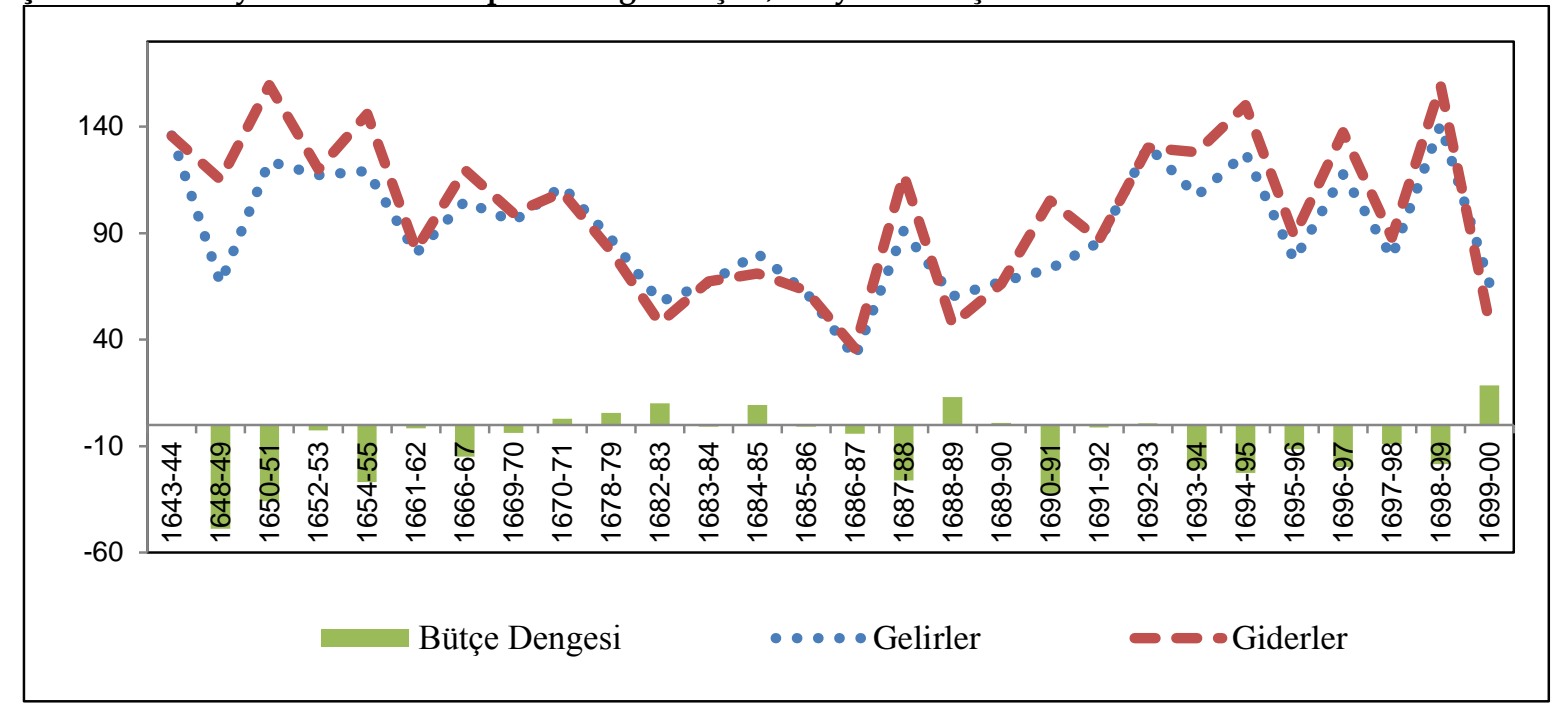

Kaynak: Mehmet Genç ve Erol Özvar (2006); “Osmanlı Maliyesi Kurumlar ve Bütçeler 2", Osmanlı Bankası Arşiv ve Araştırma Merkezi, İstanbul; Ahmet Tabakoğlu (2005); “İktisat Tarihi Toplu Makaleler I", Kitabevi Yayınları; Halil Sahillioğlu (1967); "Sıvış Yılı Buhranları", İktisat Fakültesi Mecmuası, Cilt 27, Sayı 1-2; Erol Özvar (2006); “Osmanlı Devletinin Bütçe Harcamaları (1509-1788)", Osmanlı Maliyesi Kurumlar ve Bütçeler 1 (Hazırlayanlar: Mehmet Genç ve Erol Özvar), Osmanlı Bankası Arşiv ve Araştırma Merkezi, İstanbul çalışmalarından tarafımızca derlenmiş ve düzenlenmiştir.

Bu yüzyılda uzun, masraflı ve yıpratıcı savaşların bütçe üzerindeki etkisini görmek mümkündür. 1669/70 bütçe yılına kadar birçok yılda (1643/44 yılı hariç) bütçe açıkları oluşmuştur. 1669/70 yılından 1686/87 yılına kadar birçok yılda bütçe fazlası gerçekleşmiş, bu yıldan itibaren bütçe dengesi birçok yılda açık vermiştir. Eser (1982:190)'e göre 1669/70 yılı bütçe giderlerinin

$\% 62,5^{\prime} \mathrm{i}$ ordu ve donanma, \%30'unu saray giderleri oluşturmuştur. Bütçelerin genel olarak savaş yıllarında (1683 II. Viyana bozgunu ve sonrasinda Avusturya, Lehistan, Venedik ve Rusya ile girişilen uzun savaş yılları) çoğunlukla açık verdiği, barış yıllarında fazla verdiği söylenebilir. Şekilde de görüldüğü gibi 1699 Karlofça barışı ve sonrası bütçelerinde bu eğilimi görmek mümkündür.

Şekil 2: 17. Yüzyılda Osmanlı İmparatorluğu Bütçe Dengesinin Bütçe Gelir ve Giderlerine Oranı, \%

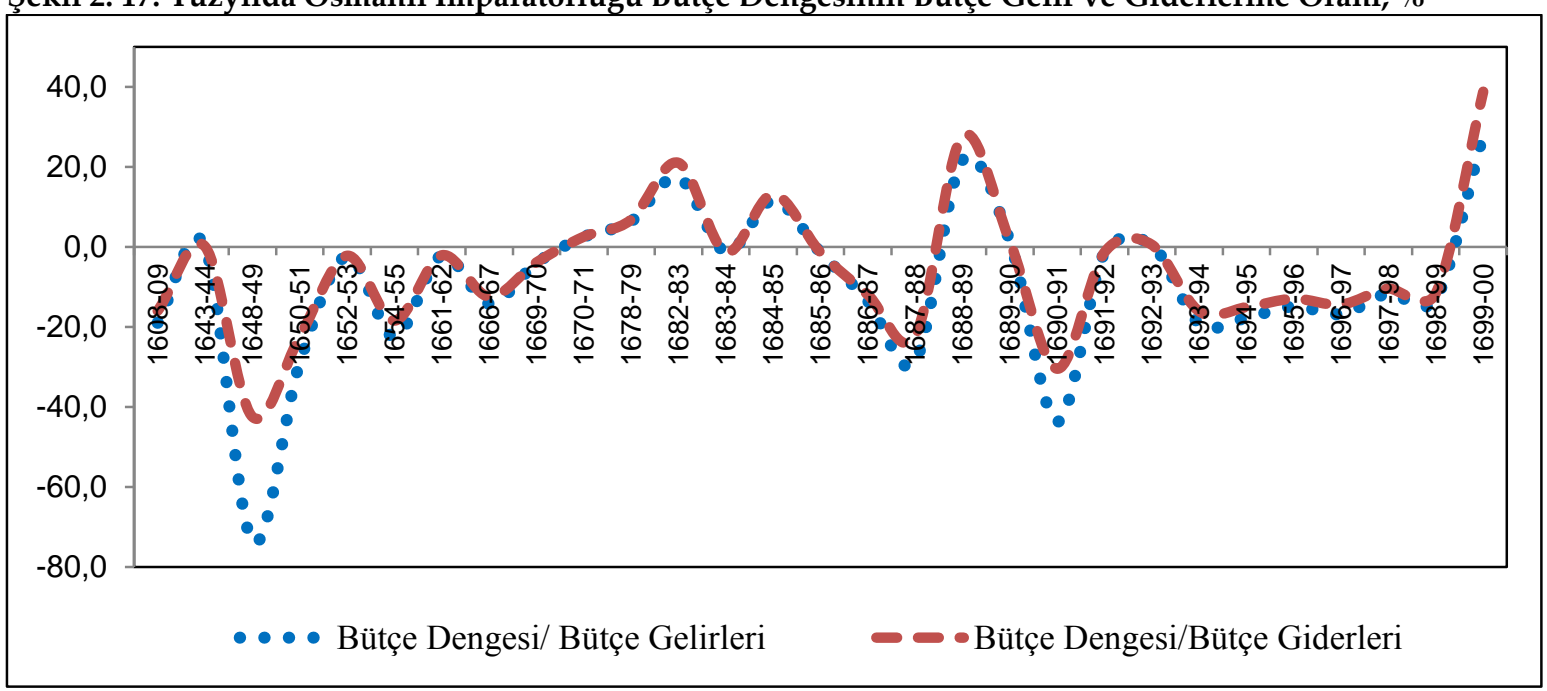

Kaynak: Mehmet Genç ve Erol Özvar (2006); “Osmanlı Maliyesi Kurumlar ve Bütçeler 2”, Osmanlı Bankası Arşiv ve Araştırma Merkezi, İstanbul; Ahmet Tabakoğlu (2005); “İktisat Tarihi Toplu Makaleler I", Kitabevi Yayınları; Halil Sahillioğlu (1967); "Sıəı̧̧ Yılı Buhranları", İktisat Fakültesi Mecmuası, Cilt 27, Sayı 1-2; Erol Özvar (2006); “Osmanlı Devletinin Bütçe Harcamaları (1509-1788)", Osmanlı Maliyesi Kurumlar ve Bütçeler 1 (Hazırlayanlar: Mehmet Genç ve Erol Özvar), Osmanlı Bankası Arşiv ve Araştırma Merkezi, İstanbul çalışmalarından tarafımızca derlenmiş ve düzenlenmiştir.

AKÜ IİBF Dergisi-Cilt: XVII Sayı: 2 Yıl: Aralık 2015 Sayfalar: 159-175

Journal of Economics and Administrative Sciences- Volume: XVII Issue: 1 Year: December 2015 Pages: 159-175 
17. yüzyılda bütçe açıklarının bütçe gelirlere oranı birçok yılda \%15'e, 1648/49 yılında \%74'e, 1690/91 yılında ise \%44'e ulaşmıştır. Bütçe fazlasının gelir ve gidere oranı ise 1682/83 yılında $\% 21$ 'e, 1688/89 yılında \%27'ye, 1699-1700 yılında ise \%38'e yükselmiştir (Şekil 2).

\subsubsection{Yüzyılda Osmanlı İmparatorluğu'nda Bütçe Gelişmeleri}

18. yüzyılın başında Osmanlı İmparatorluğu ekonomisi toparlanmakla birlikte yüzyllın ortalarına doğru tekrar sıkıntılı döneme dönmüştür. Bu nedenle 18. yüzyıl hakkında yapılan çalışmalarda genellikle ikili bir dönemlendirme yapılmaktadır. İlk dönemde savaşların galibiyetle sonuçlandığı ve iktisadi yapının iyi bir durumda olduğu belirtilmektedir. İlk dönem bütçelerinde yaşanan iyileşmenin bir bölümü bozulan tımar sistemi sonucunda birçok vergi kaynağının mukataalaştırılması, başka bir ifadeyle, bütçeye nakdi gelir getirecek kalemlere dönüştürülmesinden ve yeni vergilerin ihdas edilmesinden kaynaklanmıştır (Genç, 2013:201).

İkinci dönem olarak adlandırılan yüzyılın ikinci yarısına doğru sık sık savaşların yaşanması ve uzun sürmesi imparatorluk maliyesi üzerinde büyük bir yük oluşturmuş ve iktisadi-mali anlamda olumsuzluklara neden olmuştur (Pamuk, 2011:146). Bu olumsuz ekonomik ve mali gelişmeler bütçe açıklarının süreklilik kazanmasına yol açmış ve bütçe açıklarını giderecek kaynaklar yeterli olmayınca (1704, $1718,1732,1789)$ tağşiş yapılmıştır. İç kaynak sağlama amaçlı kullanılan tağşiş, son derece maliyetli bir yöntem haline gelmiş, tağşiş nedeniyle oluşan yüksek enflasyon Osmanlı dış ticaretini olumsuz etkilediği gibi vergi gelirlerinin de azalmasına yol açmıştır (Pamuk, 2012:186).

İmparatorluk bu yüzyılda malikâneciler", sarraflar ve ayanlar ile büyük bir mücadeleyle karşı karşıya kalmıştır. 17. ve 18. yüzyıllarda brüt kamu gelirlerinin yalnızca dörtte biri, masraflar çıktıktan sonra net vergi gelirlerinin ise yalnızca üçte biri merkezi devlet hazinesine girmiş, kalanı ise yukarıda belirtilen aracıların elinde kalmıştır. $\mathrm{Bu}$ aracıların varlığının, bütçe açıklarının artmasına neden olduğu aşikârdır. Bütçe açıklarının finansmanında fevkalade yollara da başvurulmuş, bu yollar arasında dikkat çekici olan ise devletin terekeler üzerindeki müdahalelerinde meydana gelen değişme olmuştur. Devlet, askeri sınıf mensuplarının terekelerine el koyabilme yetkisine öteden beri sahip ise de bu hakkı pratikte kullanmamıştır. Ancak 1770'lerden itibaren İmparatorluk bu hakkı artan bir yoğunlukla kullanmaya başlamış, zengin şahısların terekelerine de el koymayla hız kazanmıştır (Genç, 2013:217-218)

\footnotetext{
${ }^{4}$ Mukataaların en fazla 3 yıllık süresi uzatılarak açık artırmayı kazanan kişiye ölene kadar vergileri toplama hakkı tanınmıştı. Bu koşullarda özel kişilere devredilen mukataalara malikâne adı veriliyordu
}

(Pamuk, 2011:149). 1695 yılında iltizam sisteminden vazgeçilerek malikâne sistemine geçilmiş, böylece bir nevi uzun vadeli kredi temin edilmiş, nakit ihtiyacı karşılanmak istenmiştir. 
Şekil 3: 18. Yüzyılda Osmanlı İmparatorluğu Bütçe Dengesi, Milyon Kuruş

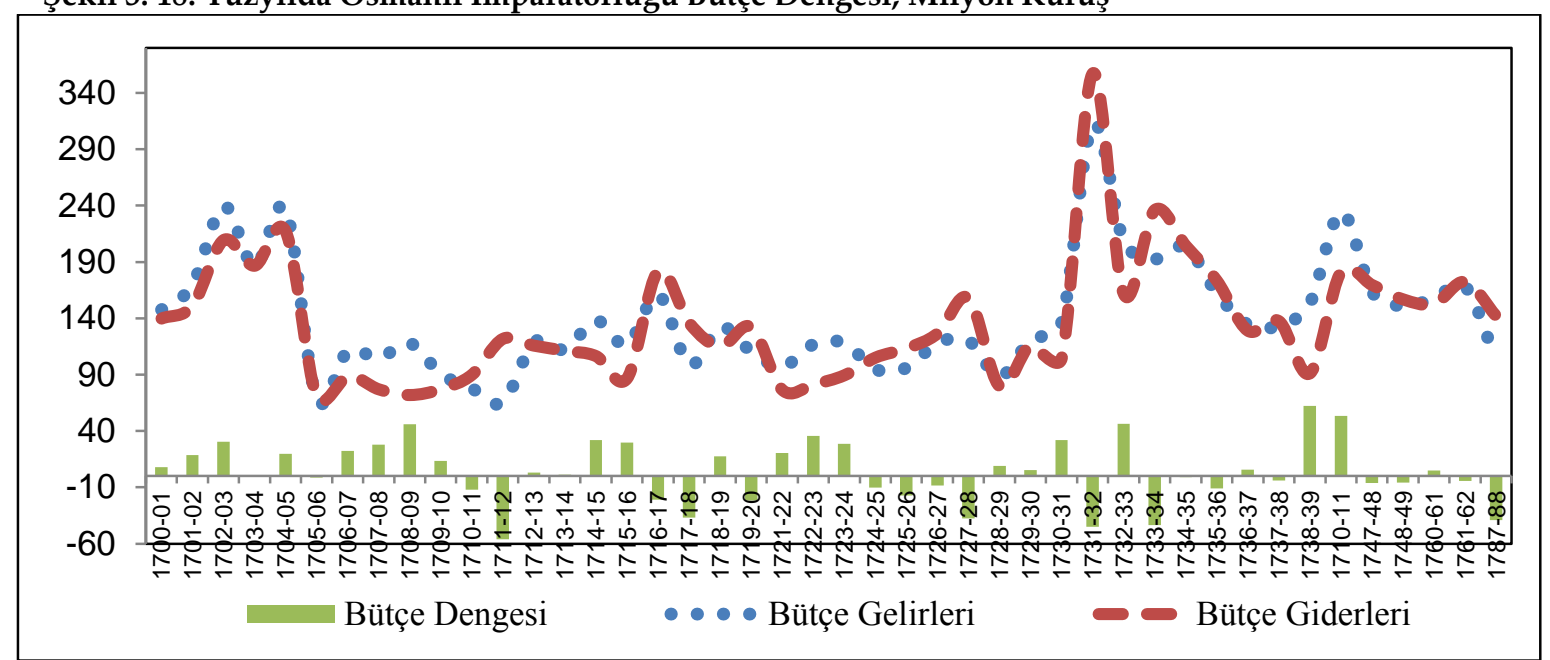

Kaynak: Mehmet Genç ve Erol Özvar (2006); “Osmanlı Maliyesi Kurumlar ve Bütçeler 2”, Osmanlı Bankası Arşiv ve Araştırma Merkezi, İstanbul; Ahmet Tabakoğlu (2005); “İktisat Tarihi Toplu Makaleler I", Kitabevi Yayınları; Halil Sahillioğlu (1967); "Sııış Yılı Buhranları", İktisat Fakültesi Mecmuası, Cilt 27, Sayı 1-2; Erol Özvar (2006); “Osmanlı Devletinin Bütçe Harcamaları (1509-1788)", Osmanlı Maliyesi Kurumlar ve Bütçeler 1 (Hazırlayanlar: Mehmet Genç ve Erol Özvar), Osmanlı Bankası Arşiv ve Araştırma Merkezi, İstanbul çalışmalarından tarafımızca derlenmiş ve düzenlenmiştir.

Şekil 3'te görüldüğü gibi 18. yüzyılın ilk yarısında birçok yılın bütçe verileri bulunmaktadır. Bütçe gelir ve giderleri yüzyılın başında yaklaşık 200 milyon kuruş iken 17051730 yıllarında yaklaşık 100 milyon kuruş seviyesinde gerçekleşmiştir. 1731/32 yılında bütçe gelir ve giderleri yaklaşık 350 milyon kuruşa yükselmiş, sonraki yıllarda tekrar azalma eğilimine girmiştir. Bu yüzyılda bütçe gelirleri ortalama 141 milyon kuruş (en düşük 66 milyon, en yüksek 312 milyon kuruş); bütçe giderleri ise ortalama 136 milyon kuruş (en düşük 72 milyon, en yüksek 357 milyon kuruş) gerçekleşmiştir. 18. yüzyıl bütçe gelir ve giderleri, ortalama olarak, 17. yüzyıl bütçelerinden yaklaşık \%30-40 daha yüksek gerçekleşmiştir.
Bütçe dengesi, dalgalı bir seyir izlemekle birlikte, genel olarak yüzyılın ilk yarısında fazla lehine oluştuğu görülmektedir. 1711/12 yılında gerçekleşen bütçe açı̆̆ının nedeni olarak Prut Savaşı gösterilebilir. Cezar (1986:29), 1768-1774 Osmanl1-Rus Savaşı'ndan önce Osmanlı Devleti'nin mali durumunun oldukça iyi olduğunu ve hatta bütçe fazlasının olduğunu ancak savaşın uzun sürmesi ve başarısızlıkla sonuçlanması nedeniyle bütçe giderlerinin artığını, bu yüzden imparatorluğun ağır bir bunalımın içine girdiğini ifade etmektedir. Nitekim İmparatorluk bu savaşın maliyetini azaltmak, Rusya'ya ödenecek tazminatı temin etmek ve mali krizden çıkmak için 1775 yılında "esham" uygulamasıyla iç borçlanmaya gitmiştir (Akar, 2001:101).

\footnotetext{
${ }^{5}$ Eshamın kelime anlamı "Pay, Hisse"dir. Sistem, mukataa adı verilen vergi gelirlerinin faiz diye
} adlandırılan belirli bir nakdi kısmının birden çok özel şahıslara muaccele adıyla satılmasıdır.

AKÜ İ̈BF Dergisi-Cilt: XVII Sayı: 2 Yıl: Aralık 2015 Sayfalar: 159-175

Journal of Economics and Administrative Sciences- Volume: XVII Issue: 1 Year: December 2015 Pages: 159-175 
Şekil 4: 18. Yüzyıl Osmanlı İmparatorluğu Bütçe Dengesinin Bütçe Gelir ve Giderlerine Oranı, \%

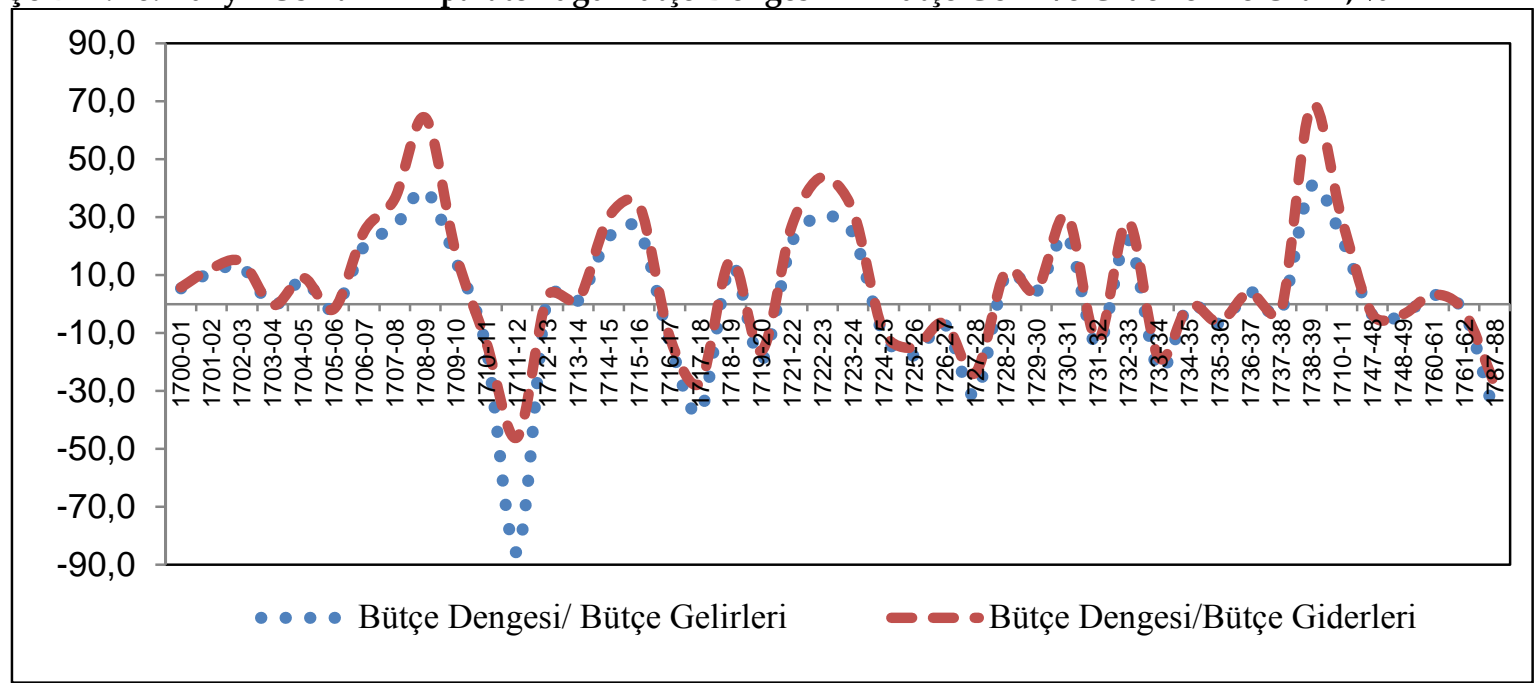

Kaynak: Mehmet Genç ve Erol Özvar (2006); “Osmanlı Maliyesi Kurumlar ve Bütçeler 2”, Osmanlı Bankası Arşiv ve Araştırma Merkezi, İstanbul; Ahmet Tabakoğlu (2005); “iktisat Tarihi Toplu Makaleler I", Kitabevi Yayınları; Halil Sahillioğlu (1967); "Sııış Yılı Buhranları", İktisat Fakültesi Mecmuası, Cilt 27, Sayı 1-2; Erol Özvar (2006); "Osmanlı Devletinin Bütçe Harcamaları (1509-1788)", Osmanlı Maliyesi Kurumlar ve Bütçeler 1 (Hazırlayanlar: Mehmet Genç ve Erol Özvar), Osmanlı Bankası Arşiv ve Araştırma Merkezi, İstanbul çalışmalarından tarafımızca derlenmiş ve düzenlenmiştir.

Osmanlı İmparatorluğu bütçesi 18. yüzyılın ilk yarısında birçok yılda fazla vermiş, bütçe fazlasının giderlere oranı 1708/09 yılında \%64'e, birçok yılda \%30'a ve 1738/39 yılında \%68'e oranı ise $1711 / 12$ yılında $\% 46$, baz1 y1llarda $(1717 / 18,1727 / 28,1787 / 88)$ \%20'ye yükselmiştir. 1711/12 yılında bütçe açı̆̆ının gelirlere oranı \%85,6' dır (Şekil 4). Bütçe fazla ve açıklarının gelir ve giderlere oranının yüksek olması mali istikrarın olmadığı göstermektedir.

\subsubsection{Yüzyılda Osmanlı İmparatorluğu'nda Bütçe Gelişmeleri}

19. yüzyılda İmparatorluk, iktisadi, mali ve yönetim anlamında buhranlı döneme girmiştir. Nitekim varlığının tehlikeye girdiği bir dönemde, imparatorluk ile ayanlar arasında 1808 yılında Sened-i İttifak imzalanmış, ancak bu anlaşma kısa bir süre sonra geçerliliğini yitirmiş, merkezi devletin gelirlerinin istikrarlı bir şekilde toplanamamasına neden olmuştur. Bu dönemde, bürokratlar devletin mali buhrandan çıkışının

\footnotetext{
6 Tanzimat Fermanı'nı (Ortaylı, 2009:114), Yavuz Cezar (1986:21) tarafından "Sonun Başlangıcı" olarak addedilmektedir. Gerçekten de mali sistem açısından din temelli bir mali yapıya sahip olan Osmanlı Devletinde her vatandaşın vergilendirilme kapsamında eşit sayılması ve aynı vergilere muhatap
}

sağlam bir mali tabanın oluşturulmasına bağlı olduğunu ifade etmişler, bu amaçla mali alanda köklü reformlara gidilmiş, 17 . ve 18 . yüzyıllardaki iktisadi ve mali alandaki hâkimiyeti tekrar kazanma amacı güdülmüştür (Güran, 1989:79-80). Bu bağlamda III. Selim (1789-1807) döneminde merkezi devletin gücünü artırmaya yönelik başlatılan askeri ve mali reformlar, uzun vadede Osmanlı İmparatorluğuna önemli yararlar sağlamış ve 1839 Tanzimat Fermanı ${ }^{6}$ ile ileriye taşınmıştır (Karaman ve Pamuk, 2009:28).

Dönem içinde bütçe gelirleri önemli miktarda artmış, bu artışta özellikle tarım ürünleri üretiminin artışı ve buna paralel olarak ithalat ve ihracatın artışı etkili olmuştur. Öte yandan giderek malî bürokrasinin etkinliğinin artışı ve daha önce büyük ölçüde aynî yükümlülükler şeklinde düzenlenen bazı vergilerin Tanzimat döneminde (1839-1876) nakdî yükümlülüklere çevrilmesi gelirleri artırmıştır (Güran, 2003:11).

Tanzimat'la birlikte ayrıca malikâne ve esham sisteminin kaldırılması ve tımar sisteminin

tutulması vergilendirme sistemindeki MüslümanGayri Müslüman şeklindeki ayrıma son vermiştir. Bu gelişmeler ise sonraki süreçte Gayri Müslümanlardan alınan cizye vergisinin dönüşmesine neden olmuştur (Yeşilyurt, 2015:104105). 
tasfiyesi amaciyla reformlar yapilmaya başlanmıştır. Böylece devlet, artık vergileri aracilar vasitasıyla değil kendisinin toplayacağını ilan etmiştir. Ancak bu önemli karar başarısız olmuş ve vergi gelirleri önemli miktarda düşmüştür. Bundan dolayı devlet, 1842 yılında tekrar iltizam sistemine dönmüştür. Bununla birlikte devlet toplanan vergi gelirleri içerisindeki aracıların payını düşürmeyi başarmış, vergilerin toplanmasında taşradaki aracilarla anlaşma yerine demiryolu ve telgraf gibi teknolojilerden ve askeri kuvvetlerden yararlanma yoluna gitmiştir (Karaman ve Pamuk, 2009:32).

Tanzimat Fermanı'nda bütçe kavram olarak yer almamiş, ancak savunma ve diğer kamu hizmetlerinin yapılması için zorunlu giderlerin kanunlarla önceden sinırlandırılması ve tespit edilmesi gereğine işaret edilmiştir. Tanzimat'tan sonra geleneksel defterdarlık teşkilatı kaldırılarak yerine Maliye Nezareti'nin kurulması malî denetim ve organizasyonda merkeziyetçi eğilimleri güçlendirmiş ve bütçe alanındaki düzenlemelere önemli katkı sağlamıştır (Şahin, 2013:854).

$\mathrm{Bu}$ düzenlemelerin başında bütçelerin uygulanmasında ve denetiminde etkinliğin artırılması amacıyla egzersiz usulünün kabulü gelmektedir (Güran, 1989:81). Egzersiz usulüne göre, bütçedeki gelir ve giderler hangi yıla ait ise o yilın gelir ve gideri kabul edilmekte ve bu kapsamda gerekli kayıtlar yapılmaktadır.

$\mathrm{Bu}$ yüzyılda bütçe giderlerinin önemli bir bölümünü savunma giderleri oluşturmuş, giderlerinin diğer bölümünü iç işleri, dış işleri, maliye ve vakıflar gibi idarî birimlerin memur maaşları ile diğer giderler oluşturmuştur. Bütçedeki geleneksel idari giderlerin bir bölümünü sultanın ve sarayın harcamaları meydana getirmiştir (Güran, 2003:6).

\footnotetext{
7 Osmanlı İmparatorluğu bütçe yapısında gelirler Güneş yılı (Miladi Takvim) hesabına göre, giderler ise Ay yılı (Hicri Takvim) hesabına göre tutulmaktaydı. Bu iki takvim hesabından meydana gelen 11 günlük fark neticesinde 33 yılda bir artık 1 yıl ortaya çıkmakta ve bütçe dengesini bozmaktadır. $\mathrm{Bu}$ olumsuzluk, her dönemde yaşanmakta ise de; devletin askeri ve mali anlamda güçlü olduğu dönemlerde etkisi pek de hissedilmemekte iken 17. Yüzyıl ve sonrasında meydana gelen güçsüzlükler
}

19. yüzyılda bütçe açılarındaki artış seyrini genel olarak konjonktürel, ekonomik ve sosyal nedenler şeklinde sıralamak mümkündür. Konjonktürel nedenler bağlamında ilk olarak Osmanlı İmparatorluğu aleyhine işleyen kapitülasyonlar gelmektedir. Farklı dönemlerde farklı amaçlar için uygulanan kapitülasyonlar, bu dönemde devlet aleyhine işleyen bir fonksiyon üstlenmiş, devletin gelir ihtiyacını artırmıştır. Bütçe açıklarını olumsuz etkileyen bir diğer konjonktürel etki ise, Osmanlı maliye sisteminde "sııış yıll $\imath^{7 "}$ olarak adlandırılan, iki farklı takvim yapısının kullanmasından kaynaklanan 33 yılda 1 yıllık artık yılın meydana gelmesi durumudur (Sahillioğlu, 1967:76). Bütçe açıkların ekonomik nedenleri olarak ise askeri harcamalarda artışlar, devlet kadrolarındaki şişmeler, üretim yetersizlikleri, gelir düşüklükleri ve cülus bahşişlerinin artışı gösterilebilir (Şeker, 2007:118120).

Bütçe açıklarının neticeleri olarak toplumsal huzursuzlukların ve ayaklanmaların artması ve güvensizlik ortamının yaygınlaşması, köyden şehre göçün artması ve yönetim kademesinde yolsuzluk ve rüşvet faaliyetlerin yaygin hale gelmesi gösterilebilir (Şeker, 2007:118-120).

Öte yandan bütçe açıklarını finanse etmek için borçlanma süreci başlamıştır. Osmanlı Devleti, bütçe açıklarını, ilk olarak, Galata bankeri olan gayr-1 Müslimlerden temin ettiği borçlarla finanse etme yoluna gitmiştir. 19. yüzyılın ortalarına doğru ise malî piyasalarda meydan gelen olumsuzluklar sebebiyle bankerlerden alınan borçlar bütçe açıklarını kapatamaz duruma gelmiştir. Nitekim 1879 yılında Osmanlı Devleti, başta Osmanlı Bankası olmak üzere iç borç veren Galata Bankerlerinin isteği doğrultusunda Rüsum-u Sitte İdaresi'nin ${ }^{8}$ kurulmasını kabul etmiştir.

\footnotetext{
"Sııış Yılının" Osmanlı maliyesindeki etkisini ortaya koymaktadır (Sahillioğlu, 1967:76-80).

8 Anlaşma metninde yer alan gelir türü sayısı 6 olduğu için "Rüsum-u Sitte İdaresi" (Altı Vergi İdaresi) adı verilmiştir. Anlaşma gereği 6 adet vergi gelirinin 10 yıl süreyle (1879-1880) önceki yıllardan 8.725.000 lira alacaklı oldukları kabul edilen Galata Bankerlerine bırakılması uygun görülmüştür (Özdemir, 2010:74).
} 
Öte yandan bazı devlet adamlarının karşı çıkmasına rağmen ilk olarak 1853/56 Kırım Savaşı'nda dış borçlanmaya başvurulmuştur. $\mathrm{Bu}$ yıldan itibaren dış borçlanma mali sıkıntıların giderilmesinde ve bütçe açklarının kapatılmasında en belirgin yöntem olmuştur. Ancak bu yöntem, elde edilen gelirlerin katma değer üretecek alanlara aktarılamaması ve cari harcamalarda kullanılmasından dolayı mali anlamda ağır sonuçların ortaya çıkmasına neden olmuştur (Pamuk, 2006:36-37). Nitekim imparatorluk 1876 yılında dış borçların ödenemeyeceğini ilan etmiş, 1881 yılında devlet gelir kaynaklarından bir bölümünü ${ }^{9}$ borçların ödenmesi amaciyla Düyun-u Umumiye İdaresi' ${ }^{10}$ ne devretmek zorunda kalmıştır.

Şekil 5: 19. Yüzyılda Osmanlı İmparatorluğu Bütçesi, Milyon Kuruş

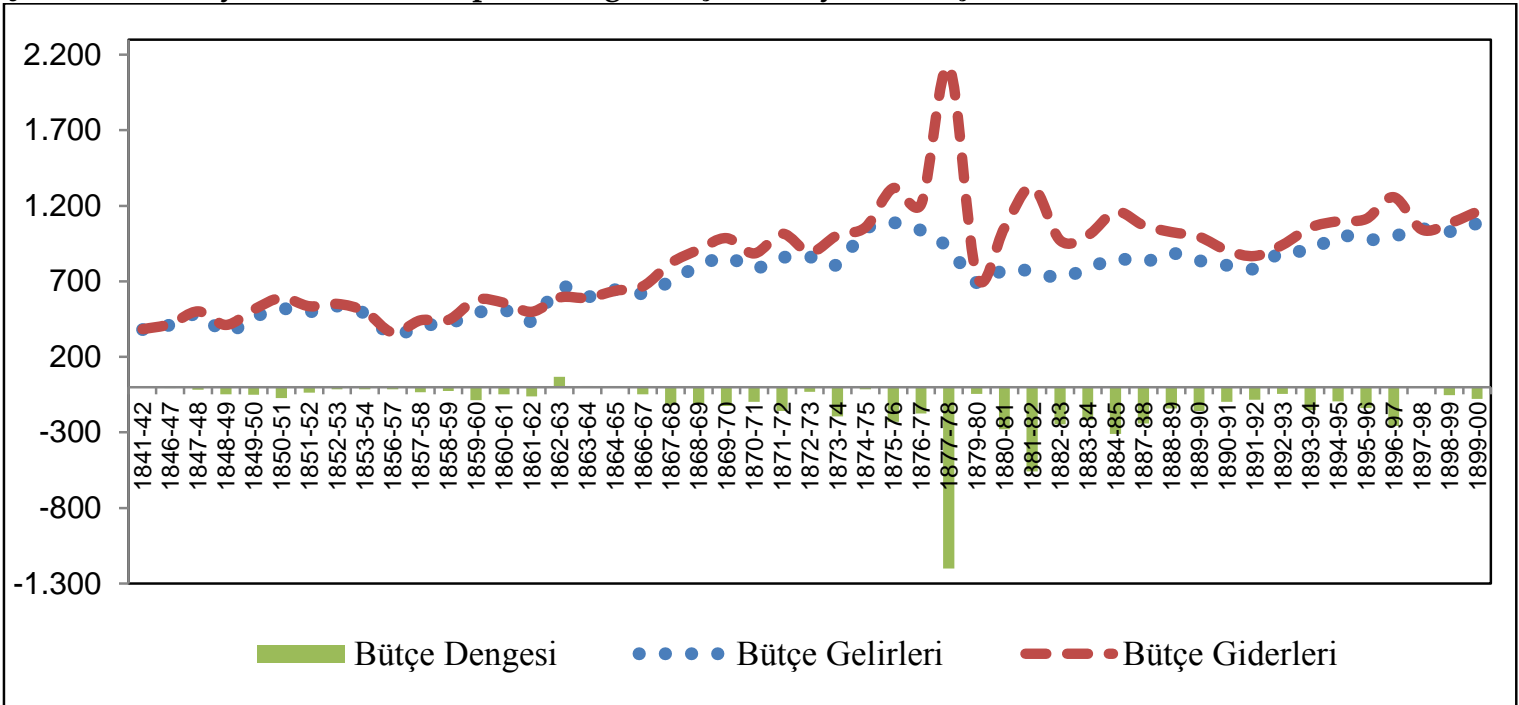

Kaynak: Tevfik Güran (2006); “Osmanlı Kamu Maliyesi, 1839-1918”, Osmanlı Maliyesi Kurumlar ve Bütçeler 1

(Hazırlayanlar: Mehmet Genç ve Erol Özvar), Osmanlı Bankası Arşiv ve Araştırma Merkezi, İstanbul çalı̧masından tarafımızca derlenmiş ve düzenlenmiştir.

Şekil 5 incelediğinde, 1841/42 yılından itibaren bütçe verilerin olduğu görülmektedir. Bu dönemde genel olarak bütçe gelir ve giderlerinin atış eğiliminde olduğu, ancak birçok yılda giderlerdeki artışı daha yüksek olduğu görülmektedir. Bu yüzyılda bütçe gelirleri ortalama 729 milyon kuruş (en düşük 344 milyon, en yüksek 1088 milyon kuruş); bütçe giderleri ise ortalama 854 milyon kuruş (en düşük 360 milyon, en yüksek 1318 milyon kuruş) gerçekleşmiştir. 19. yüzyıl bütçe gelir ve giderleri, ortalama olarak, 18 yüzyıl bütçelerinden yaklaşık 6 kat daha yüksektir. Öyleki, yüzyılın başında bütçe gelir ve giderleri yaklaşık 400 milyon kuruş iken yüzyılın sonunda 1 milyar kuruşa yaklaşmıştır. $\mathrm{Bu}$ durum bütçe gelirlerinin artışı yönünden olumlu gözükmekle birlikte bütçe giderlerinin daha hızlı artığı görülmektedir.

\footnotetext{
${ }^{9}$ Devletin vergi v.b. gelirlerinin $\% 25-30$ 'u bu idareye bırakılmıştır (Ulusoy, 2013:172).

10 Düyun-u Umumiye İdaresi, yedi üyeli bir meclisten oluşmaktaydı. İdare, İngiliz ve Hollandalı alacaklıları temsilen bir üye, Fransız, Alman,
}

Bütçe gelir ve giderlerindeki düşme yönündeki değişmelerin temel nedeni savaşların yol açtı̆̆ ciddî toprak kayıplarıdır. 1856'da zengin Romanya toprakları Osmanlı denetiminin dışına çıkmış; 1877/78 Osmanl1-Rus savaşı sonucunda Bosna, Hersek, Bulgaristan, Kafkaslar, Kars, Ardahan ve Kıbrıs kaybedilmiştir. Nitekim bu toprak kayıpları ile imparatorluk nüfusunun üçte birini kaybetmiştir. Bu kayıpların malî ve ekonomik sonuçları daha da olumsuz olmuştur. Çünkü Avrupa'da kaybedilen bölgeler ekonomik standartları itibariyle imparatorluk ortalamasının oldukça üzerinde olan en gelişmiş bölgelerdi (Güran, 2003: 10-11).

Bu dönemin ilk bütçelerinde cüz'i bir bütçe açı̆̆ 1 söz konusudur. Kırım Savaşı (1853-1856)'nda 1.4 milyar kuruşa yakın savaş harcaması bütçe tertibi dışında tutulduğundan bütçe açıkları artmamış

Avusturyalı, İtalyan alacaklılarının temsilen birer üye, Osmanlı Devleti ve mümtaz tahsilat sahiplerini temsilen bir üyeden oluşmaktaydı (Ulusoy, 2013:172). 
(Güran, 2003: 10-11), takip eden ylllarda bütçe açıkları dalgalı bir seyir izlemiştir. Yukarıda bahsedildiği üzere 1877/78 Osmanl1-Rus savaş1 bütçe dengelerini alt üst etmiş, ciddî nüfus ve toprak kayıpları nedeniyle yüksek bütçe açıları gerçekleşmiştir. II. Abdülhamit iktidarının (18761909) ilk yıllarında önemli miktarlara ulaşan borç ödemelerine rağmen bütçe açıkları, dalgalı bir seyir izlemekle beraber, azalma eğilimi göstermiştir.

Tanzimat'la birlikte mali alanda gerçekleştirilen düzenlemelerin bütçe gelirlerini önemli miktarda artırdığını ve gelir toplamada etkin bir politika uyguladığını ortaya koymaktadır. Ancak aynı başarının bütçe giderlerinde yakalandığını söylemek çok mümkün değildir.

Şekil 6: 19. Yüzyılda Osmanlı İmparatorluğu Bütçe Dengesinin Bütçe Gelir ve Giderlerine Oranı, \%

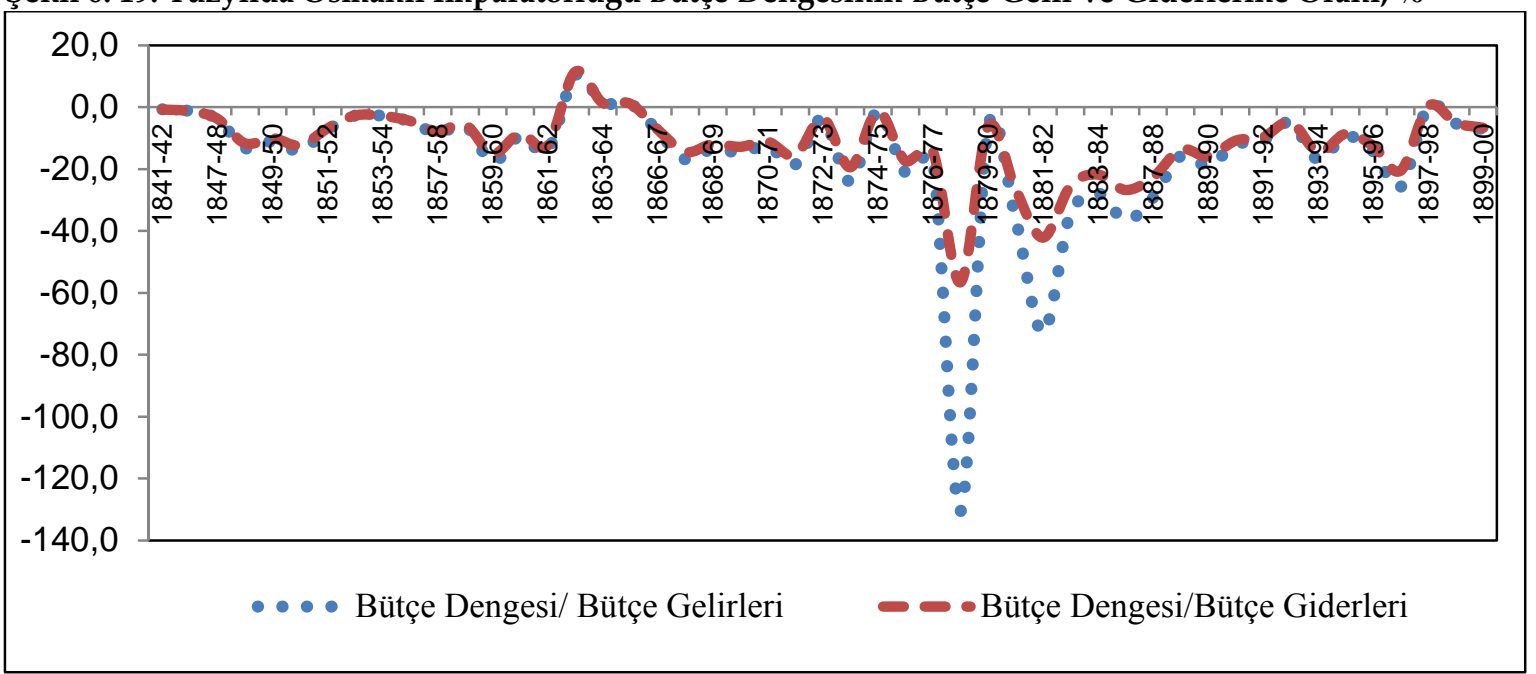

Kaynak: Tevfik Güran (2006); "Osmanl Kamu Maliyesi, 1839-1918”, Osmanlı Maliyesi Kurumlar ve Bütçeler 1 (Hazırlayanlar: Mehmet Genç ve Erol Özvar), Osmanlı Bankası Arşiv ve Araştırma Merkezi, İstanbul çalışmasında yer alan bütçe rakamları tarafımızca derlenmiş ve oluşturulmuştur.

Şekil 6'de görüleceği üzere birçok yılda bütçe gelir ve giderlerinin \%15-20'si kadar bütçe açığı gerçekleşmiştir. Kırım savaşı öncesinde bütçe açıları, 1849/50 malî yılı dışında, gerek miktar ve gerekse devlet giderlerine oranı itibariyle önemsiz düzeyde kalmıştır. Ancak bütçe açığı 1861/62 malî yılında devlet giderlerinin \%12,4'üne ulaşmış, gelirlerinin giderleri karşılama oranı \%87,6'ya inmiştir. Bu tarihten sonra bütçe açıkları dalgalı bir seyir izleyerek bazı yıllarda çok küçük miktarlara inmiş, ancak 1875/76 malî yılında bütçe giderlerinin \%17,4'üne yükselmiştir.

Bütçe açı̆̆ının gelir ve giderlere oranının, 18701890 yıllarında daha yüksek olduğu görülmektedir. Öyleki 1877/88 yılında bütçe açığının bütçe giderine oranı \%56'ya, bütçe gelirine oranı ise \%130'a yükselmiştir. Bütçe açığının bütçe giderlerine oranı Düyun-u Umumiye İdaresi'nin kurulduğu 1881/82 yılında $\% 30$ 'un üzerinde iken 1887/88 yılına kadar \%20'lerin üzerinde kalmış, bu tarihten sonra dalgalı bir seyir izlemekle beraber sürekli azalma eğilimi göstermiştir.

\subsection{Yüzyılda Osmanlı İmparatorluğu'nda Bütçe Gelişmeleri}

Osmanlı İmparatorluğu, 20. yüzyılda varlığını 22 yıl sürdürebilmiş, 1922 yılında saltanatın kaldırılmasıyla sona ermiştir. Osmanlı İmparatorluğu'nun bu son döneminde siyasi, iktisadi ve mali sorunlar artık giderilemeyecek bir boyuta erişmiş ve devletin varlığ tartışmalar yaşanmıştır. Böyle bir konjonktürün yaşanmasını tetikleyen unsurların başında iktisadi ve mali konular gelmektedir.

Nitekim Osmanlı İmparatorluk tarihinde hemen hemen her aşamada görülen kapitülasyonlar özellikle son dönemlerde bütçe dengesinin bozulmasında ve kronik bir hale dönüşmesinde önemli bir rol oynamıştır. Yabancı tüccarların Osmanlı'ya ihraç ettiği ya da Osmanlı'dan satın aldıkları mallar üzerindeki vergilerde indirim yapılması, tüccarların yerleşme özgürlüğü olması ve kişisel vergilerden muaf tutulmaları gibi uygulamaların etkileri bu dönemde derinleşmiş ve Osmanlı maliyesinde yıkıcı bir etkiye dönüşmüştür (Berkes, 2013:195; Kazgan, 
1999:26). Öte yandan azınlıklara tanınan haklar ve ayrıcalıkların yoğun olması nedeniyle vergi gelirlerinin çoğunun taşrada tarımla uğraşan köylüden alınması, bu kesim üzerinde ağır yükler oluşturmuştur (Kepenek ve Yentürk, 2001:10-11).

Bu yüzyılda geniş alanlara yayılan devletlerarası savaşların yoğun yaşanma mali yapıyı olumsuz etkilemiştir. Özellikle Balkan Savaşları ve I. Dünya savaşının tarafı olan ve savaşın merkezi konumunda bulunan Osmanlı İmparatorluğu, iktisadi ve mali anlamda bu savaşlardan derinden etkilenmiştir. Öyleki bu yıllarda ihtiyaçları karşılamak, savaşı finanse etmek ve bütçe açıklarını kapatmak amacıyla olağanüstü bir vergi toplama örneği olan Tekâlif-i Harbiye $^{11}$ ye başvurulmuştur (Tezcan, 2005:50). Öte yandan dış borçların sürekli artışı ve borçların katma değer oluşturacak sektörlere aktarılamaması Osmanlı İmparatorluğu'nu yıkıma götüren iktisadi ve mali unsurlar arasında yer almıştır (Kepenek ve Yentürk, 2001:10-11).

\section{Şekil 7: 20. Yüzyılda Osmanlı İmparatorluğu Bütçesi, Milyon Kuruș}

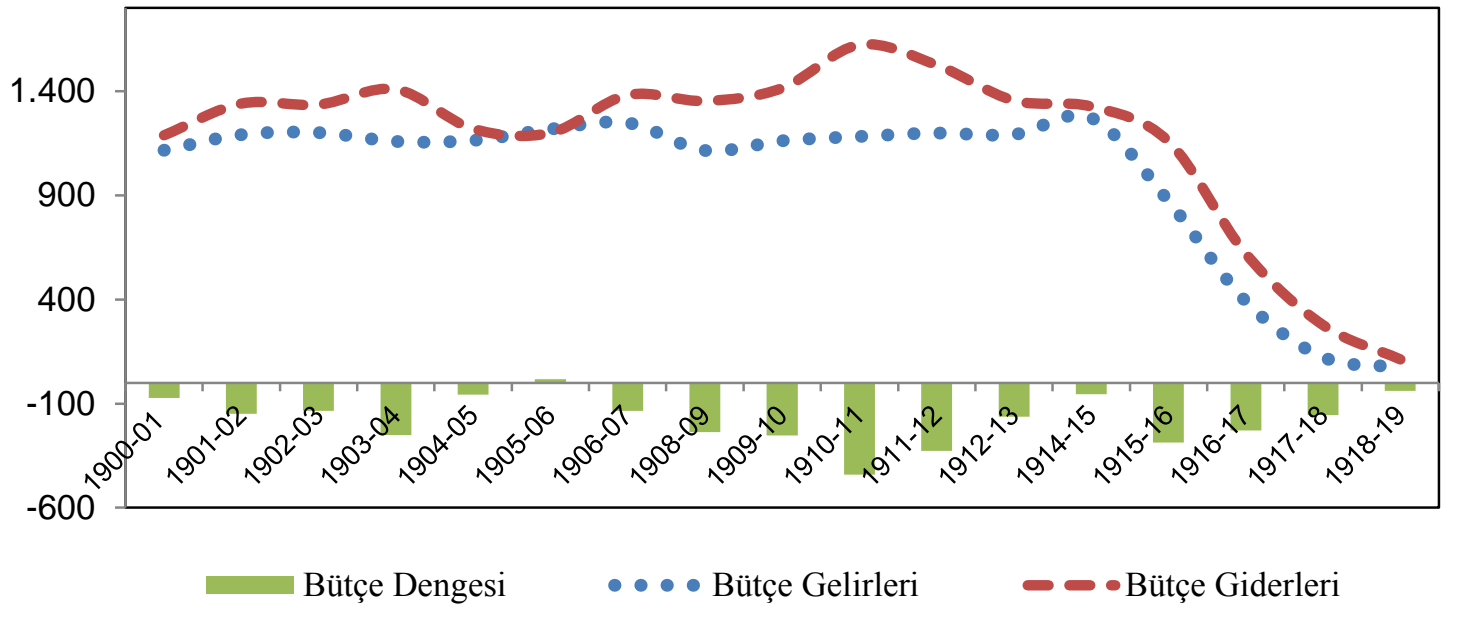

Kaynak: Tevfik Güran (2006); "Osmanl Kamu Maliyesi, 1839-1918”, Osmanlı Maliyesi Kurumlar ve Bütçeler 1 (Hazırlayanlar: Mehmet Genç ve Erol Özvar), Osmanlı Bankası Arşiv ve Araştırma Merkezi, İstanbul çalışmasında yer alan bütçe rakamları tarafımızca derlenmiş ve oluşturulmuştur.

Osmanlı İmparatorluğunda yaşanan iktisadi ve mali bunalımı Şekil 7'da görmek mümkündür. Bütçe gelir ve giderleri, I. Dünya Savaşı (19141918)'na kadar yatay bir seyir izlemiş, sonrasında hızla azalmıştır. Dünya Savaşı öncesinde bütçe gelirleri ortalama 1.187 milyon kuruş (en düşük 1.116 milyon, en yüksek 1.272 milyon kuruş); bütçe giderleri ise ortalama 1.360 milyon kuruş (en düşük 1.189 milyon, en yüksek 1.623 milyon kuruş) gerçekleşmiştir.
Bu dönemde hazırlanan 17 bütçeden sadece 1905/06 bütçesi fazla verirken diğerleri ise açık vermiştir. Balkan Savaşları (1912-1913) ve özellikle I. Dünya Savaşı'nda bütçe açıkları oldukça yükselmiştir. Ayrıca bütçe açıklarının sadece savaş dönemlerinde değil; aynı zamanda savaş öncesindeki hazırlıklar neticesinde yaşandığı görülmektedir.
11 Tekalif-i Harbiye, Osmanlı Devletinde, 25 Ağustos 1912'de Balkan Savaşları sırasında alınması kararlaştırılan ancak 9 Ağustos 1914'te çıkarılan ek bir kanun ile I. Dünya Savaşı esnasında, geri ödeneceği vaadiyle özellikle ordunun ihtiyaçlarını karşılamak amacıyla ihtiyaç duyulan eşyalar üzerine konulan bir olağanüstü vergidir (Tezcan, 2005:1-4). 
Şekil 8: 20. Yüzyılda Osmanlı İmparatorluğu Bütçe Dengesinin Bütçe Gelir ve Giderlerine Oranı, \%

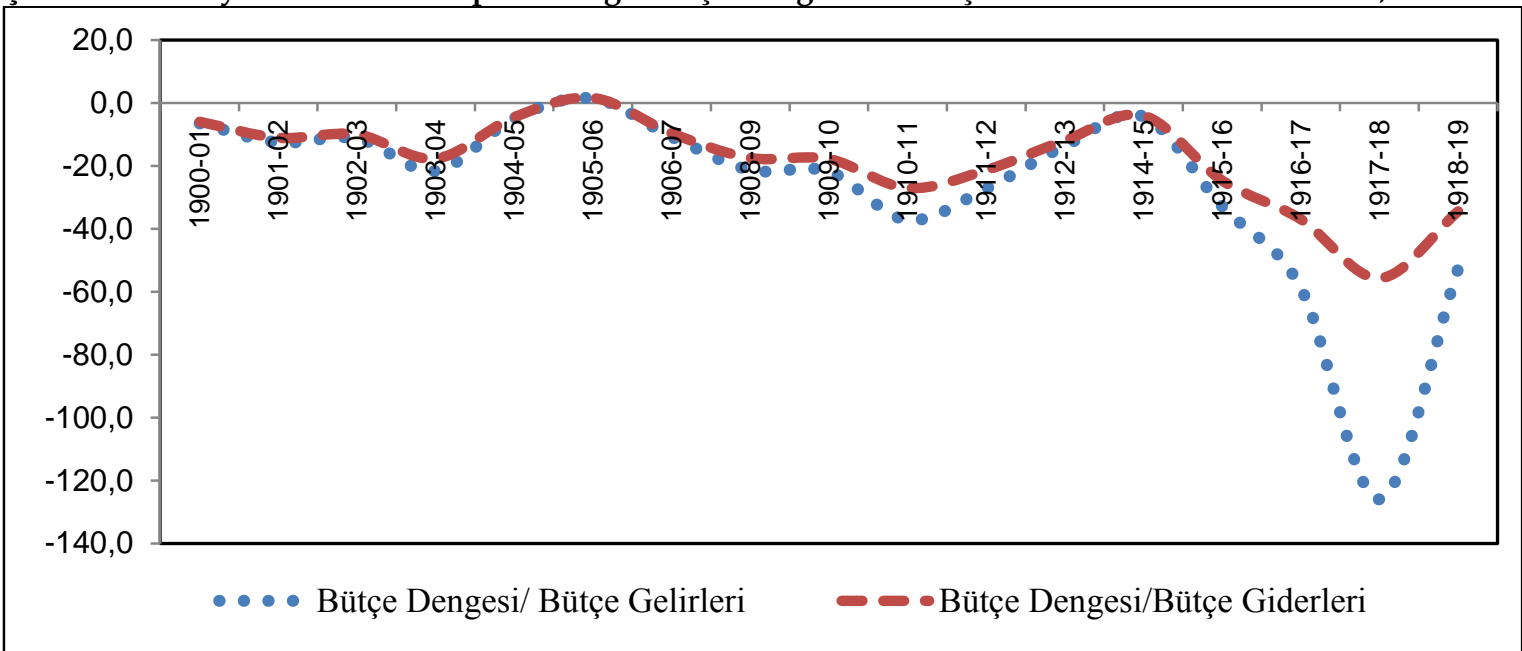

Kaynak: Tevfik Güran (2006); “Osmanl Kamu Maliyesi, 1839-1918”, Osmanlı Maliyesi Kurumlar ve Bütçeler 1 (Hazırlayanlar: Mehmet Genç ve Erol Özvar), Osmanlı Bankası Arşiv ve Araştırma Merkezi, İstanbul çalışmasında yer alan bütçe rakamları tarafımızca derlenmiştir ve oluşturulmuştur.

Şekil 8'de görüldüğü üzere bütçe açıklarının bütçe gelirlerine oranı birçok yılda \%20'ye, 19091912 yıllarında ise \%30'a yükselmiştir. Öyleki bütçe dengesinin bütçe gelirlerine oranı

\section{SONUÇ}

Bütçeler, devletlerin gelirleri, harcamaları ve dolayısıyla bu iki kesim arasındaki dengeyi göstermektedir. Osmanlı İmparatorluğu'nda bütçe geleneğinin olduğu, ancak bu bütçeler ile gerek batılı ülkelerde gerekse de günümüz modern parlamenter sistemlerde kullanilan bütçeler arasında bir takım farklılıkların olduğu yadsınamaz bir gerçekliktir. Bununla birlikte Osmanlı maliyesinin en köklü geleneklerinden biri olan bütçe kayıtları, merkezi hazinenin gelir ve giderlerini en küçük ayrıntılarına kadar takip etmemize olanak tanımaktadır. Bu bağlamda çalışmada Osmanlı maliyesinde yaklaşık 300 yıllık bir süreçte 138 yılın bütçesi analiz edilebilmiştir. Çalışmada, uzun bir zaman dilimin olması dolayısıyla cari rakamlar Şevket Pamuk tarafından oluşturulan İstanbul Tüketici Fiyatları Endeksi (1469-1918) kullanılarak reel hale dönüştürülmüştür.

17. yüzyıl bütçeleri, merkeziyetçi yapıya gidiş sonucu, taşra eyaletlerinin gelir ve giderleri merkez maliye teşkilatının kalemlerine dağıtılmış bir yapıya sahipti. Bütçe gelir ve giderleri, genel eğilim olarak yüzyılın başından 1686/87 yılına kadar yarıdan fazla azalmış, bu yıldan sonra tekrar artarak yüzyılın başındaki 1917/18'de \%126'ya yükselmiştir. Bu yıllarda savaş nedeniyle potansiyel kamu gelirlerinin azalması ya da toplanamaması ve savunma harcamaları başta olmak üzere giderlerdeki hızlı artış bütçe açıklarını artırmıştır.

değerlere ancak ulaşmıştır. Kaybedilen savaşların sayısının artması, mali sistemin bozulması ve reform çalışmaları merkezi yönetimin kaynak ihtiyacını artırmıştır. Birçok yılda gerçekleşen bütçe açıklarının finansmanında tağşiş ve iç borçlanma kullanılmıştır. İç hazinenin yanı sıra sarraflardan iç borç alınmaya başlanmış, bu ilişki sonraki yüzyıllarda artarak devam etmiştir.

18. yüzyılın başında Osmanlı İmparatorluğu ekonomisi toparlanmaya başlamış, birçok vergi kaynağının bütçeye nakdi gelir getirecek kalemlere dönüştürülmesi ve yeni vergilerin ihdas edilmesi bütçe gelirlerini artırmıştır. Ancak yüzyılın ortalarına doğru sık sık savaşların yaşanması ve uzun sürmesi imparatorluk maliyesi üzerinde büyük bir yük oluşturmuştur. Bütçe gelir ve giderleri, yüzyılın başında yaklaşık 200 milyon kuruş iken 1705-1730 yıllarında yaklaşık 100 milyon kuruşa gerilemiş, 1731/32 yılında bütçe gelir ve giderleri yaklaşık 350 milyon kuruşa yükselmiş, sonraki yıllarda tekrar azalma eğilimine girmiştir. 18. yüzyıl bütçe gelir ve giderleri, ortalama olarak 17. yüzyıl bütçelerinden \%30-40 daha yüksek gerçekleşmiştir. Bu yüzyılın, özellikle, ikinci 
yarısında bütçe açıklarını giderecek kaynaklar yeterli olmayınca sık sık yapılan tağşiş nedeniyle yüksek enflasyon oluşmuş, bu durum vergi gelirlerinin de azalmasına yol açmıştır. Bütçe açılarının finansmanında, malikâneciler, sarraflar ve ayanlar ile karşı karşıya kalınmış, askeri sınıf mensuplarının yanı sıra zengin özel şahısların terekelerine de el koyulmaya başlanmış ve iç borçlanmaya devam edilmiştir.

19. yüzyılda İmparatorluk, iktisadi, mali ve yönetim anlamında buhranlı döneme girmiş, devletin gücünü artırmaya yönelik askeri ve mali reformlar başlatılmıştır. Bu dönemde genel olarak bütçe gelir ve giderlerinin atış eğiliminde olduğu, ancak birçok yılda giderlerdeki artışın gelir artışlarının üzerinde gerçekleştiği görülmüştür. 19. yüzyıl bütçe gelir ve giderleri, ortalama olarak, 18 yüzyıl bütçelerinden yaklaşık 6 kat daha yüksektir. Öyleki, yüzyılın başında bütçe gelir ve giderleri yaklaşık 400 milyon kuruş iken yüzyılın sonunda 1 milyar kuruşa yaklaşmıştır. Öte yandan bütçe açıklarını finanse etmek için Galata bankerlerinden borçlanma yoluna gidilmiş, bu borçlanma yüzyılın ortalarına doğru yetersiz kalınca dış borçlanma, bütçe açıklarının kapatılmasında en belirgin yöntem olmuş, ancak elde edilen gelirlerin katma değer üretecek alanlara aktarılamaması ve cari harcamalarda kullanılmasından dolayı mali anlamda ağır sonuçların ortaya çıkmasına neden olmuştur.

Osmanlı İmparatorluğu'nun son yüzyılında siyasi, iktisadi ve mali sorunlar artık giderilemeyecek bir boyuta erişmiştir. Kapitülasyonlar, özellikle bu dönemde bütçe dengesinin bozulmasında ve kronikleşmesinde önemli bir rol oynamıştır. Bütçe gelir ve giderleri, I. Dünya Savaşı'na kadar yatay bir seyir izlemiş, sonrasında hızla azalmıştır. $\mathrm{Bu}$ dönemde

azınlıklara tanınan haklar ve ayrıcalıkların yoğun olması nedeniyle vergi gelirlerinin çoğunun taşrada tarımla uğraşan köylüden alınması, bu kesim üzerinde ağır yükler oluşturmuştur. Öte yandan Balkan Savaşları ve I. Dünya savaşı mali yapıyı olumsuz etkilemiş; potansiyel kamu gelirlerinin azalması ya da toplanamaması ve savunma harcamaları başta olmak üzere giderlerdeki hızlı artışlar bütçe açıklarını artırmıştır.

Sonuç olarak Osmanlı İmparatorluğu'nun ekonomik, toplumsal ve mali yapısındaki bozulma kendini bütçe açıkları şeklinde göstermiştir. Uygulanan birçok reform neticesinde, özellikle 19. yüzyılda, bütçe gelirleri önemli miktarda artmasına rağmen bütçe giderlerinin daha hızlı artışı bütçe açıklarını sürekli hale getirmiştir. Öte yandan bütçe açıklarının finansmanı için iltizam yöntemi, tağşiş, iç borçlanma ve diş borçlanmaya başvurulmuştur. Ancak sık sık yapılan tağşişler nedeniyle oluşan yüksek enflasyonun vergi gelirlerinin de azalmasına yol açması ve bütçe gelirlerinin giderek artan bir kısmının iç ve dış borç anapara ve faiz geri ödemesinde kullanılması bütçe açıklarını tekrar artırmıştır. Daha açık bir ifadeyle İmparatorluk özellikle 19. yüzyıldan itibaren "bütçe açığı-borçlanma-bütçe açı̆̆ı" kısır döngüsüne girmiştir. Öyleki Osmanlı İmparatorluğu'nun 1879 yılında Rüsum-u Sitte İdaresi'nin kurulmasıla iç ekonomik bağımsızlı̆̆ını; 1881 yılında ise Düyun-u Umumiye İdaresi'nin kurulmasıyla dış ekonomik bağımsızlığını kaybettiği söylenebilir. Özetle toplumsal, ekonomik ve mali yapıdaki bozulmanın göstergesi olan bütçe açıkları ve neticesinde borçlanma süreci Osmanlı İmparatorluğu'nu ekonomik ve mali yıkıma götüren en önemli unsurlar arasında yer almıştır. 


\section{KAYNAKÇA}

Akar, Şevket Kamil (2001); “Osmanlı Devleti'nde Kısa ve Uzun Vadeli İç Borçlanmanın Gelişimi”, İstanbul Üniversitesi Iktisat Fakültesi Mecmuası, C. 51, S. 2, 99-124.

Bağlı, Mehmet Selim (2012); “Teorik ve Tarihsel Açıdan Bütçe Hakkı”, Yasama Dergisi, Sayı 20, s. 39-77

Barkan, Ömer Lütfi (1955); “Osmanlı İmparatorluğu Bütçelerine Dair Notlar”, İstanbul Üniversitesi İktisat Fakültesi Mecmuası, Cilt 17, Sayı 1-4, s. 193-224.

Berkes, Niyazi (2013); Türkiye İktisat Tarihi, Yapı Kredi Yayınları, İstanbul

Cezar, Yavuz (1986); Osmanlı Maliyesinde Bunalım ve Değişim Dönemi (XVIII. yy.dan Tanzimat'a Mali Tarih), Alan Yayıncılık, İstanbul.

Çakır, Baki (2006); "Geleneksel Dönem (Tanzimat Öncesi) Osmanlı Bütçe Gelirleri”, Osmanlı Maliyesi Kurumlar ve Bütçeler 1 (Hazırlayanlar: Mehmet Genç ve Erol Özvar), Osmanlı Bankası Arşiv ve Araştırma Merkezi, İstanbul

Eser, Uğur (1982); Osmanlı İmparatorluğu Bütçeleri: Bir İnceleme, Ekonomik Yaklaşım, 3(7): 169-194

Feyzioğlu, Bedi N. (1983); “Modern Anayasalarda Bütçe Hakkı”, İstanbul Üniversitesi İktisat Fakültesi Maliye Araştırma Merkezi Konferansları, Seri 29, 3-28

Genç, Mehmet (2013); Osmanlı İmparatorluğunda Devlet ve Ekonomi, 9. Basım, Ötüken Yayınları, İstanbul

Genç, Mehmet ve Erol Özvar (2006); Osmanlı Maliyesi Kurumlar ve Bütçeler 2, Osmanlı Bankası Arşiv ve Araştırma Merkezi, İstanbul

Güran, Tevfik (1989); Tanzimat Döneminde Osmanlı Maliyesi: Bütçeler ve Hazine Hesapları (1841-1861), Türk Tarih Kurumu Yayınları, XXV. Dizi, Sayı 8, Ankara

Güran, Tevfik (2003), Osmanlı Mali İstatistikleri Bütçeler:1841-1918, Tarihi İstatistikler Dizisi Cilt 7, T. C. Başbakanlık Devlet İstatistik Enstitüsü, Ankara, Türkiye.

Güran, Tevfik (2006); “Osmanlı Kamu Maliyesi, 1839-1918”, Osmanlı Maliyesi Kurumlar ve Bütçeler 1 (Hazırlayanlar: Mehmet Genç ve Erol Özvar), Osmanlı Bankası Arşiv ve Araştırma Merkezi, İstanbul

Gürsakal, Gürsu Galip (2010), “Osmanlı ve Büyük Güçlerin Askeri Harcamalarına Karşılaştırmalı Bir Bakış (1840-1900)", Akademik Bakış, c:4, S:7, s:115-131.

http://www.maliye.gov.tr/Tarihce/Bakanl\%C4\%B1k\%20Tarihcesi\%20.pdf.

Karaman, Kıvanç ve Şevket Pamuk (2009); "Osmanlı Bütçeleri ve Mali Yapının Evrimi”, Toplumsal Tarih, Sayı 191, s. 26-33

Kazgan, Gülten (1999); Tanzimat'tan XXI. Yüzyıla Türkiye Ekonomisi, Altın Kitaplar Yayınevi, İstanbul

Kepenek, Yakup ve Nurhan Yentürk (2001); Türkiye Ekonomisi, Remzi Kitapevi, 12. Bask1, İstanbul

Ortaylı, İlber (2009); İmparatorluğun En Uzun Yüzyıll, 29. Baskı, Timaş Yayınları, İstanbul

Özdemir, Biltekin (2010); Osmanlı Devleti Dış Borçları (1854-1914 Borçlanmaları, Galata Bankerleri ve Osmanlı Bankası, Duyun-u Umumiye İdaresi, Türkiye Cumhuriyet'inin Kabul Ettiği Osmanlı Devlet Borçları), İkinci Baskı, T.C. Maliye Bakanlığı Strateji Geliştirme Başkanlığı, Ankara, Şubat.

Özvar, Erol (2006); “Osmanlı Devletinin Bütçe Harcamaları (1509-1788)”, Osmanlı Maliyesi Kurumlar ve Bütçeler 1 (Hazırlayanlar: Mehmet Genç ve Erol Özvar), Osmanlı Bankası Arşiv ve Araştırma Merkezi, İstanbul

Pamuk, Şevket (2000); İstanbul ve Diğer Kentlerde 500 Yillık Fiyatlar ve Ücretler (1469-1998), Başbakanlık Devlet İstatistik Enstitüsü Yayın No. 2397, Ankara. 
Pamuk, Şevket (2006); "Osmanlı Devletinin İç Borçlanma Kurumlarının Evrimi”, Osmanlı Maliyesi Kurumlar ve Bütçeler 1 (Hazırlayanlar: Mehmet Genç ve Erol Özvar), Osmanlı Bankası Arşiv ve Araştırma Merkezi, İstanbul

Pamuk, Şevket (2011); Osmanlı-Türkiye İktisadi Tarihi: 1500-1914, 7. Baskı, İletişim Yayınları, İstanbul

Pamuk, Şevket (2012); Osmanlı İmparatorluğunda Paranın Tarihi, Türk Tarih Kurumu Yayınları, 5. Baskı, İstanbul

Parlak, Müslüm ve Zeliha Parlak (2012), "Osmanlı Mali Sistemi ve Divan-1 Muhasebata Giden Yol", Sayıştay Dergisi, Sayı:87, Ekim - Aralık 2012, 18-38.

Sahillioğlu, Halil (1967); “Sıvış Yılı Buhranları”, İktisat Fakültesi Mecmuası, Cilt 27, Sayı 1-2, s. 75-111.

Sahillioğlu, Halil (1985); "1524 - 1525 Osmanlı Bütçesi”, İktisat Fakültesi Mecmuası, Cilt 41, Sayı 1-4, 415449 .

Şahin, Harun (2013), “Osmanlı Bütçe Sisteminin Tekâmülü, 1839-1922", International Journal of Social Science, Volume 6 Issue 2, p. 853-868,

Şeker, Murat (2007); "Osmanlı Devletinde Mali Bunalım ve İlk Dış Borçlanma", Cumhuriyet Üniversitesi İktisadi ve İdari Bilimler Dergisi, Cilt 8, Say1 2, s. 115-134

Tabakoğlu, Ahmet (1985); “XVII. ve XVIII. Yüzyıl Osmanlı Bütçeleri”, İ.Ü.I.F.M Ord. Ömer Lütfi Barkan'a Armağan, Cilt: 41, No:1-4, 389-414.

Tabakoğlu, Ahmet (2005); İktisat Tarihi Toplu Makaleler I, Kitabevi Yayınları, İstanbul

Tabakoğlu, Ahmet (2006); “Osmanlı Devletinin İç Hazinesi”, Osmanlı Maliyesi Kurumlar ve Bütçeler 1 (Hazırlayanlar: Mehmet Genç ve Erol Özvar), Osmanlı Bankası Arşiv ve Araştırma Merkezi, İstanbul

175 Tezcan, Cezmi (2005); Tekalif-i Harbiye ve Tekalif-i Milliye Örneklerinde Savaş Dönemleri Mali Politikaları, Yayınlanmamış Doktora Tezi, Ankara Üniversitesi Türk İnkılap Tarihi Enstitüsü, Ankara

Tüğen, Kamil (2014); Devlet Bütçesi, 13. Baskı, İzmir

Ulusoy, Ahmet (2013); Devlet Borçlanması, 7.Baskı, Celepler Matbaacılık, Trabzon.

Yeşilyurt, Şahin (2015); Din ve Ekonomi Bağlamında İslam Maliye Tarihi ve Maliye Sistemi, Gazi Kitabevi, Ankara

Yılmaz, H. Hakan ve Mustafa Biçer (2010); “Parlamentonun Bütçe Hakkını Etkin Kullanımının Yeni Bütçe Sistemi Çerçevesinde Değerlendirilmesi”, Maliye Dergisi, Sayı 158, s. 201-225. 